\title{
Coccolith arrangement follows Eulerian mathematics in the coccolithophore Emiliania huxleyi
}

\author{
Kai Xu ${ }^{1,2}$, David Hutchins ${ }^{3}$, Kunshan Gao ${ }^{\text {Corresp. } 2}$ \\ ${ }^{1}$ College of Fisheries, Jimei University, Xiamen, Fujian, China \\ 2 State Key Laboratory of Marine Environmental Science, Xiamen University, Xiamen, Fujian, China \\ 3 Department of Biological Sciences, University of Southern California, Los Angeles, California, United States \\ Corresponding Author: Kunshan Gao \\ Email address: ksgao@xmu.edu.cn
}

Background. The globally abundant coccolithophore, Emiliania huxleyi, plays an important ecological role in oceanic carbon biogeochemistry by forming a cellular covering of plate-like $\mathrm{CaCO}_{3} \mathrm{Crystals}$ (coccoliths) and fixing $\mathrm{CO}_{2}$. It is unknown how the cells arrange different-size of coccoliths to maintain full coverage, as the cell surface area of the cell changes during daily cycle.

Methods. We used Euler's polyhedron formula and CaGe simulation software, validated with the geometries of coccoliths, to analyze and simulate the coccolith topology of the coccosphere and to explore the arrangement mechanisms.

Results. There were only small variations in the geometries of coccoliths, even when the cells were cultured under variable light conditions.Because of geometric limits, small coccoliths tended to interlock with fewer and larger coccoliths, and vice versa. Consequently, to sustain a full coverage on the surface of cell, each coccolith was arranged to interlock with four to six others, which in turn led to each coccosphere contains at least 6 coccoliths.

Conclusions. The number of coccoliths per coccosphere must keep pace with changes on the cell surface area as a result of photosynthesis, respiration and cell division. This study is an example of natural selection following Euler's polyhedral formula, in response to the challenge of maintaining a $\mathrm{CaCO}$ ${ }_{3}$ covering on coccolithophore cells as cell size changes. 
1 Coccolith arrangement follows Eulerian mathematics in the coccolithophore Emiliania

2 huxleyi

$3 \mathrm{Kai} \mathrm{Xu}^{1,2}$, David A Hutchins ${ }^{3}$, Kunshan Gao ${ }^{1 *}$

$4{ }^{1}$ State Key Laboratory of Marine Environmental Science, Xiamen University, Xiamen, China

$5 \quad 2$ Fisheries College, Jimei University, Xiamen, China (current address)

$6{ }^{3}$ Department of Biological Sciences, University of Southern California, Los Angeles, California, 7 USA

8

9 * Corresponding Author: Kunshan Gao (ksgao@xmu.edu.cn) 


\section{Abstract}

12 Background. The globally abundant coccolithophore, Emiliania huxleyi, plays an important

13 ecological role in oceanic carbon biogeochemistry by forming a cellular covering of plate-like

$\mathrm{CaCO}_{3}$ crystals (coccoliths) and fixing $\mathrm{CO}_{2}$. It is unknown how the cells arrange different-size of coccoliths to maintain full coverage, as the cell surface area of the cell changes during daily cycle.

17 Methods. We used Euler's polyhedron formula and CaGe simulation software, validated with the geometries of coccoliths, to analze and simulate the coccolith topology of the coccosphere and to explore the arrangement mechanisms.

Results. There were only small variations in the geometries of coccoliths, even when the cells were cultured under variable light conditions. Because of geometric limits, small coccoliths tended to interlock with fewer and larger coccoliths, and vice versa. Consequently, to sustain a full coverage on the surface of cell, each coccolith was arranged to interlock with four to six others, which in turn led to each coccosphere contains at least 6 coccoliths.

Conclusions. The number of coccoliths per coccosphere must keep pace with changes on the cell surface area as a result of photosynthesis, respiration and cell division. This study is an example of natural selection following Euler's polyhedral formula, in response to the challenge of maintaining a $\mathrm{CaCO}_{3}$ covering on coccolithophore cells as cell size changes. 


\section{Introduction}

The structure of a normal, complete Emiliania huxleyi coccolith includes two oval-shaped shields connected by a central tube (Young et al. 1992). The coccoliths are curved and interlocked with neighboring coccoliths to match the spherical morphology of the cell membrane (Young et al. 2017; Young et al. 2003). Generally, in healthy, rapidly growing E. huxleyi cells, a layer of interlocking coccoliths fully and smoothly covers the protoplast surface, forming the socalled coccosphere. Thus, the coccosphere is generated when a cell arranges a group of interlocking coccoliths to fully cover the cell surface. In addition, the E. huxleyi coccoliths vary in size among morphotypes, strains, within strain-specific populations, and even frequently observed on individual cells (Paasche 2002). Although the interlocking coccolith architecture can offer exceptional mechanical protection for E. huxleyi cells (Jaya et al. 2016), the coccolith topology (the relationship between interlocking coccoliths of the coccosphere) and the arrangement mechanisms remain unknown.

Numerous studies have reported that the cell topology of many organisms follows mathematical rules. The two-dimensional (2D) Euler's formula was used in previous studies to explain why the average number of cell sides is six in many tissues, such as plant coverings, animal epithelia and seaweed (Gibson et al. 2006; Lewis 1926; Xu et al. 2017). The threedimensional (3D) Euler's formula was used to explain why the average face number of cells is approximately 14 in soap froth and many multicelled organisms (Lewis 1943; Weaire \& Rivier 1984). As the basic component of the coccosphere, coccoliths are produced with a specific geometry. Thus, we propose that the formation of the coccosphere must follow some basic mathematical principles or constraints. Understanding the mathematical controls and limits of coccolith topology would be extremely useful for modeling the architecture of some extinct coccolithophore species that were rarely preserved in the fossil record, which were observed only as loose coccoliths and never as intact coccospheres (Sheward 2016). In addition, to sustain full coverage of the cell surface by coccoliths as cell cycle induces changes, there must be a link between the coccolith number and cell size. In the present study, we used Euler's polyhedron 
57 formula and $\mathrm{CaGe}$ simulation software, validated by the geometries of coccoliths and the

58

59

60

61

coccosphere, to investigate the mathematical constraints that might underpin the coccolith topology in the E. huxleyi coccosphere.

\section{Materials \& Methods}

The coccosphere diameters and geometric data of coccoliths which are presented in this study were derived from a previous study by Xu \& Gao (2015). Briefly, E. huxleyi calcifying strain CS-369 was grow in Aquil medium (Price et al. 1989) at $20^{\circ} \mathrm{C}$ at two $\mathrm{CO}_{2}$ concentrations (400 and 1,000 ppmv). The cultures were exposed to either artificial light (12 h:12 h light:dark), or solar irradiance (14 h:10 h light:dark) with and without an ultraviolet screen. The mean visible light levels during the light period were ranged from $\sim 100$ to $650 \mu \mathrm{mol} \mathrm{m} \mathrm{m}^{-2} \mathrm{~s}^{-1}$. Cultures collected at the same time point during the light period were filtered gently onto $1 \mu \mathrm{m}$ polycarbonate (Xu \& Gao 2015) or $0.22 \mu \mathrm{m}$ mixed cellulose ester filters. We examined and imaged these filters with a Philips XL30 (Xu \& Gao 2015) (Amsterdam, The Netherlands) or an LEO 1530 (Oberkochen, Germany) scanning electron microscope (SEM). The morphology of $E$. huxleyi coccoliths was characterized as follows: normal, incomplete, malformed, incomplete and malformed (Langer et al. 2011; Xu \& Gao 2015). We selected detached normal coccoliths lying flat on the filters to measure the distal shield length (DSL), distal shield width (DSW), and outer distal shield width (OSW) using the software Amscope Toupview 3.0 (Fig. 1). All of the coccolith samples from the different growth conditions were combined to explore the general mathematical principles underlying mechanisms of coccolith arrangement on the surface of the protoplast. In addition, this study also measured the length and width of oval-shaped protococcoliths lying flat on filters. The proto-coccolith ring is the initial calcite crystals of coccoliths and was previously identified as an incomplete coccolith (Langer et al. 2011; Paasche 2002; Xu \& Gao 2015; Young et al. 1992).

We define a layer of coccoliths as a group of completely interlocking coccoliths that fully covered the cell surface. In the present study, except for a few extra non-interlocked coccoliths, 
84

85

86

most visible coccoliths were completely interlocked with each other. Thus, the coccospheres examined in this study contained only one layer of coccoliths. Assuming that the coccoliths were uniformly distributed, the number of coccoliths in the coccosphere was equal to twice that of the fully interlocked coccoliths with a visible central area on the SEM photos (Fig. 1). In addition, we measured the coccosphere diameter to establish a relationship between coccolith number per coccosphere and surface area of coccosphere. We analyzed the structures of the coccospheres using Euler's polyhedral formula, where a polyhedron with $F$ faces, $V$ vertices and $E$ edges is described by $F+V-E=2$. Then, we examined and simulated data using $\mathrm{CaGe}$ (https://www.math.uni-bielefeld.de/CaGe/) (Brinkmann et al. 2010). We used SPSS 22 to test the normality of data and we applied R 3.4 .3 (http://cran.r-project.org) to calculate the probability of coccoliths with specific geometric characteristics.

\section{Results and Discussion}

Coccospheres contain only one layer of coccoliths. Extra coccoliths attached on inner coccoliths have frequently been found on the coccospheres of $E$. huxleyi, which led to the idea that E. huxleyi cells contain "multilayers" of coccoliths (Hoffmann et al. 2015; Paasche 2002; Sviben et al. 2016; Young et al. 2003). A previous study found that the movement of the protoplast membrane of the coccolithophore Coccolithus pelagicus caused the coccoliths to interlock with each other (Taylor et al. 2007). Thus, extra coccoliths were beyond the control of coccolithophore cells, because they were not directly attached to the protoplast membrane. These extra coccoliths could not completely interlock with each other and were not able to fully cover the surface, allowing them to easily detach from the cells. In general, many detached coccoliths are found in the medium when culturing E. huxleyi (Paasche 2002). In this study, a layer of coccoliths was defined as a group of completely interlocking coccoliths that fully covered the cell surface. Therefore, the E. huxleyi cells should contain only one layer of completely interlocked coccoliths, which enables full coverage by coccoliths on the protoplast surface. 
111

112

113

114

115

116

117

118

119

120

121

122

123

124

125

126

127

128

129

130

131

132

133

134

135

136

137

Number of bordering coccoliths per coccolith. The geometries of coccoliths from E. huxleyi

CS-369 were microscopcially measured (Fig. 1). The ranges of the coccosphere diameter, DSL, and DSW were found to be 3.92-8.04 $\mu \mathrm{m}(5.54 \pm 0.63 \mu \mathrm{m}), 2.05-4.38 \mu \mathrm{m}(3.04 \pm 0.40 \mu \mathrm{m})$, and 1.34-3.92 $\mu \mathrm{m}(2.47 \pm 0.38 \mu \mathrm{m})$, respectively (Table 1$)$. The average ratio of DSW/DSL was $0.81 \pm 0.07(n=1,918)$. The shields were ellipsoid-ring-shaped structures, and the space between two shields enabled the coccoliths to overlap at the shield area (Fig. 1 and 2). The coccolith layer of E. huxleyi exhibited two distinguishing features: every two neighboring coccoliths (faces) were overlapped in shields, with every three overlaps (edges) intercrossed at a junction (vertex). The edges formed an inscribed polygon, placed inside the coccolith, with each vertex on the circumference (the big ellipse) of the coccolith (Fig. 3).

The OSW ranged from 0.36 to $0.84 \mu \mathrm{m}(0.57 \pm 0.09 \mu \mathrm{m})$, and the ratio of OSW/DSL ranged from 0.15 to $0.25(0.19 \pm 0.02)$ (Table 1$)$. The calculated length and width of the central areas were, respectively, 1.90 and $1.31 \mu \mathrm{m}$, which matched the measured length $(1.86 \mu \mathrm{m})$ and width $(1.37 \mu \mathrm{m})$ of the proto-coccolith rings very well. These results were consistent with a previous study, which found that the position of the proto-coccolith ring corresponded to the base of the central tube (Young et al. 1992). The distal and proximal shields are connected by the central tube (Young et al. 1992), which indicates that the overlap of interlocking two coccoliths could not transects through the central area. According to observations in previous studies and this study, normal coccoliths are always interlocked very closely (Paasche 2002; Young et al. 2003). Thus, the coccoliths have the highest possible overlap, which could help their constant attachment to the cell surface.

By simulating the interlocking patterns on 2D planes, this study summarized three basic principles:

1. The edges of the inscribed polygon must not transects through or intersects with the central area (Fig. 1 and2). Because of the restriction of central tube, it is impossible for a coccolith to have an inscribed triangle (Table 1, Fig. 3). The ratios of OSW/DSL were normally distributed. Only when the OSW/DSL of a coccolith increased to $\geqslant 0.37$ (probability $<10^{-15}$ ) did sufficient 
138 space in the shield area enable that coccolith to interlock with three much bigger coccoliths (Fig. $1394)$.

140 2. Small coccoliths tended to interlock with fewer and larger coccoliths, and large coccoliths 141 tended to interlock with more and smaller coccoliths (Fig. 4). The second principle is very likely 142 to be a combination of Lewis's law and the Aboav-Weaire Law. According to Lewis's law, if 143 polygons are tessellated on a 2D plane, then small polygons tend to have fewer sides (linear 144 relationship between mean area of a $n$-sided polygon with $n$ ) (Lewis 1928; Weaire \& Rivier 1984). According to Aboav-Weaire Law, polygons with large numbers of sides tend to have few-sided neighbors (Weaire \& Rivier 1984). However, this principle does not mean that a greater size difference between the central coccolith and the surrounding coccoliths is better for coccolith interlock. A large ratio between the average size of the bordering coccoliths (DSL $\left.\mathrm{BCs}_{\mathrm{BC}}\right)$ and the size of the central coccolith $\left(\mathrm{DSL}_{\mathrm{CC}}\right)$ resulted in overlaps that transect through central areas, and small $\mathrm{DSL}_{\mathrm{BCs}} / \mathrm{DSL}_{\mathrm{CC}}$ resulted in loose interlock (Fig. 5).

3. The coccoliths with fewer edges tended to have high ratios of DSW/DSL (Fig. 3) and

152

OSW/DSL (Fig. 3 and 4), but the coccoliths with more edges were less sensitive to these two ratios (Fig. 3-5). If coccolith had fewer edges, then the edges tended to be close to the center of coccolith, and consequently, high ratios of DSW/DSL and OSW/DSL are needed to provide sufficient space for overlaps (Fig. 3 and 4). For coccolith with more edges, however, the edges were far away from the center, and then the overlaps were less sensitive to the size of the central area and ratio of DSW/DSL (Fig. 3-5). In addition, coccolith with smaller OSW can be fully overlapped in the shield area, and coccolith with larger OSW would be only partly overlapped (Fig. 3-5).

Our simulation found that polygons with four or more edges could be inscribed in the shield area of coccoliths and meet the noted three principles (Fig. 3). Thus, each coccolith must have four or more 4 interlocking coccoliths. The distributions of the DSL and DSW were normal, and $90 \%$ of the data were clustered in the ranges of $2.41-3.74 \mu \mathrm{m}$, and $1.90-3.11 \mu \mathrm{m}$, respectively. The $5 \%$ and $95 \%$ percentiles of DSL were $21 \%$ smaller and $23 \%$ larger than the mean, 
165

166

167

168

169

170

171

172

173

174

175

176

177

178

179

180

181

182

183

184

185

186

187

188

189

190

respectively. Thus, for the strain used in this study, the coccolith sizes had only small variations even when grown under different conditions. Assuming that a coccolith interlocks with seven others, then $\mathrm{DSL}_{\mathrm{BCs}}$ would need to be approximately $0.75-0.8$ times $\mathrm{DSL}_{\mathrm{CC}}$ (Fig. 5). The probability of such a group of eight coccolith with $0.75 \leq \mathrm{DSL}_{\mathrm{BC}} / \mathrm{DSL}_{\mathrm{CC}} \leq 0.8$ is $4.4 \times 10^{-10}$. On the basis of these analyses, the greatest possible number of edges per coccolith is six.

The observation of SEM photos also supported these conclusion: each coccolith of cells of the coccolithophore E. huxleyi interlocks with four to six bordering coccoliths (Fig. 2). E. huxleyi can sometimes produce and incorporate incomplete or malformed coccoliths into coccospheres under field and laboratory conditions (Paasche 2002; Xu \& Gao 2015). The non-normal coccoliths can cause gaps between coccoliths (Xu \& Gao 2015) (Fig. 6). In addition, incorporating of too many abnormal coccoliths may inhibit the formation of the coccosphere and compromise its defensive abilities (Langer \& Bode 2011).

Analyze coccolith topology using Euler's formula and the CaGe software. The number of coccoliths in spherical coccospheres of $E$. huxleyi varies widely, ranging from 6 to 30 coccoliths per cell (Fig. 2, Table 1). The 3D structures of coccospheres are typically cubic polyhedrons. The convex polyhedron meets Euler's polyhedral formula $F+V-E=2$, which can be expressed as:

$$
\sum(6-n) F_{n}=12
$$

where $F_{n}$ means the number of faces with $n$ edges $(4 \leq n \leq 6)$. This equation can be simplified as $2 F_{4}+F_{5}=12$, where $F_{4}$ and $F_{5}$ are the number of four- and five-edged (interlocking with four and five coccoliths) coccoliths, respectively (Grünbaum \& Motzkin 1963). Thus, the lowest coccolith number necessary to construct a complete coccosphere is six (Fig. 2, Table 1). In addition, because the equation does not set any restriction on the number of hexagons, the necessary conditions of Euler's polyhedral formula are insufficient for use in the enumeration of polyhedra (Grünbaum \& Motzkin 1963) (Supplementary Table 1). In this study, ww applied the simulation software CaGe to test for the existence of polyhedra, as deduced from Eq. (1). 
191

192

193

194

195

196

197

198

199

200

201

202

203

204

205

206

207

208

209

210

211

212

213

214

215

216

A polyhedron is a solid that contains at least four faces. Assuming a coccosphere only contains four or five coccoliths (Fig. 7), then some coccoliths should have only three edges, which would result in the average angles between neighboring coccoliths being less than $90^{\circ}$. In this way, the coccoliths must be far longer than the diameter of the protoplasm, which is not consistent with the fact that the calcification of E. hulxeyi at the diploid phase is an intracellular process (Dixon 1900; Paasche 2002; Wilbur \& Watabe 1963). This fact also supports the idea that the lowest coccolith number to construct a complete coccosphere is six (Fig. 2, Table 1), which in turn also results in that each coccolith must having four or more interlocking coccoliths. This conclusion is consistent with previous studies that have observed that other coccolithophore species, Helicosphaera carteri, Toweius pertusus, and Umbilicosphaera bramletti, have minimum numbers (five to seven) of coccoliths per cell (Gibbs et al. 2013; Sheward 2016; Sheward et al. 2017; Young et al. 2017).

Moreover, according to our calculations, if the coccolith number per coccospheres is 12 or 14 or more, then the polyhedra (coccospheres) must contain five- and six-edged faces; if the number is 13 or 12 or fewer, then they must contains four- and five-edged faces (Fig. 7, Supplementary Table 1). In addition, the polygons with four- and five edges betray the positive overall curvature (Weaire \& Rivier 1984), which indicates that the polygon composition influences the curvature of spherical cell.

Effective coverage area of coccolith. The average surface area of a coccosphere was $97.5 \mu \mathrm{m}^{2}$.

The mean DSW was very close to the mean DSL (Table 1), and then the surface area of coccolith approximately equal to the surface area of a spherical cap, with a bottom diameter equal to the mean value of DSW and DSL. The estimated surface area of a coccolith was 6.3 $\mu \mathrm{m}^{2}$ which was slightly larger $(6 \%)$ than the projected area of a coccolith on a $2 \mathrm{D}$ plane. Thus, we used the $2 \mathrm{D}$ geometric laws to approximately estimate the effective coverage area of coccolith (the area of the inscribed polygon). 
217

218

219

220

221

222

223

224

225

226

227

228

229

230

231

232

233

234

235

236

237

238

239

240

241

242

243

The area of maximum inscribed and minimum circumscribed polygons of ellipse are, respectively, $0.5 n a b \sin (2 \pi / n)$ and $n a b \tan (\pi / n)$, where $a$ and $b$ are the two semi-axes, $n$ is the number of sides ( $\mathrm{Su}$ 1987). Thus, the area of maximum inscribed ellipse of the maximum $n$-sided inscribed polygon of a coccolith is $(\cos (\pi / n))^{2}$ times the area of coccolith. The mean number of coccoliths per coccosphere was 15.4 which results in that the mean edge number of coccolith was 5.2 (Supplementary Table 1). Then, the size of the maximum inscribed ellipse was approximately equals to the mean value of the mean sizes of two ellipses of coccolith distal shield (Fig. 3), this kind of situation should be the major pattern of interlocking coccoliths because of the geometric data of coccolith had only small variations. The ratio of OSW/DSL was the key geometric constraint which ensures coccoliths reach to maximum coverage area (Fig. 3). In addition, because of more $\mathrm{CaCO}_{3}$ are needed to build the shield area than the central area, the minimum ratio of OSW/DSL also take an advantage on the efficiency of calcification.

The ratio of the area of the maximum inscribed polygon of ellipse to the ellipse area is:

$$
0.5 \times n / \pi \times \sin (2 \pi / n)
$$

where $n$ is the number of sides of polygon. Thus, the effective coverage area of a coccolith increases with an increasing number of bordering coccoliths. We used the polygon composition of coccosphere (Supplementary Table 1) and equation 2 to estimate the mean number of coccoliths per coccosphere. The estimated number was 19.7 which is higher than the observed number by $22 \%$. Thus, the method in this study underestimated the number of coccoliths per coccosphere, which could attribute to that a few coccoliths with hidden central area were not counted in the SEM photos. The estimated effective coverage area of coccolith was $4.9 \mu \mathrm{m}^{2}$. In addition, the correction on the mean number of coccoliths per coccosphere did not influence the conclusion in the above paragraph.

\section{Coccoliths per coccosphere and daily size changes. Regardless of the size difference of} coccospheres, the cells can always maintain full coverage by coccoliths (Fig. 2). Full coverage by coccoliths is sustained even during cell division (Klaveness 1972). The lowest coccolith 
244

245

246

247

248

249

250

251

252

253

254

255

256

257

258

259

260

261

262

263

264

265

266

267

268

269

270

number per coccosphere is six, which raises a question of how E. huxleyi cells sustain full coverage after division. The daughter cells may lose full coverage of coccoliths if division is triggered with less than 12 coccoliths per coccosphere. The cell, however, cannot to count the number of coccoliths. This study found that larger coccospheres of E. huxleyi used more coccoliths to cover their larger surface area $(p<0.0001$, Fig. 8$)$, which was consistent with several recent studies (Gibbs et al. 2013; Hoffmann et al. 2015; Sheward 2016; Sheward et al. 2017). Cell size is tightly regulated during the whole cell cycle to maintain the characteristic cell size of a population (Amodeo \& Skotheim 2016; Kiyomitsu 2015). Thus, we propose that $E$. hulxeyi cells divide at the proper size, which ensures that sufficient coccoliths will be allocated to the daughter cells, that is, each daughter will obtain at least six coccoliths.

Based on observations of four other coccolithophore species (Calcidiscus leptoporus, Calcidiscus quadriperforatus, Helicosphaera carteri, and Coccolithus braarudii), Sheward et al. (2017) found that the cell size and the number of coccoliths per cell of recently divided cells were smaller than for cells ready to divide. Thus, to sustain a full coverage on the protoplast, calcification must adjust to changes in the surface area. During the light period, the surface area will increase as organic carbon is fixed, resulting in cells requiring more coccoliths to maintain full coverage. Calcification primarily takes place during the light period, which sequentially produces coccoliths that join the coccosphere (Paasche 2002; Taylor et al. 2007). A large number of detached coccoliths have been found in exponentially growing cultures of E. huxleyi, which indicates that cells generally produce more coccoliths than needed to construct a coccosphere (Paasche 2002). This may be mechanical insurance for E. huxleyi cells to sustain full coverage during the light period.

During the dark period, the surface area is mainly determined by cell division and respiration. The division of E. huxleyi cells primarily occurs at night, and the population growth rate of calcifying strains can be as high as approximately two divisions per day (Paasche 2002; Xu \& Gao 2015; Zondervan et al. 2002), which means that cell numbers at the end of the dark period will be increased by as many as four times. Because of cell-to-cell heterogeneity in growth rate 
271 in the population (Damodaran et al. 2015), some cells need to divide three times per day. The

272 total surface area would increase by approximately $58 \%$ if a cell equally split into four daughter

273 cells after two sequential divisions. Previous studies reported that respiration decreased $E$.

274 huxleyi cell size and increased the ratio of calcite to organic carbon content during the dark

275 period (Paasche 2002; Zondervan et al. 2002). These findings suggest that respiration could

276 offset the effects of cell division on surface area. In addition, coccolithophores slowly calcify in

277 the dark (Paasche 2002; Taylor et al. 2007), which also offset these effects.

278 The slope of the line fit to the surface area of coccosphere and number of coccoliths per 279 coccosphere was 4.1 (Fig. 8). The effective coverage area of coccolith was $4.9 \mu \mathrm{m}^{2}$. The number 280 of coccoliths per coccosphere was underestimated by $22 \%$. Thus, the coccoliths per coccosphere 281 determined $73 \%$ of the variation of the surface area of coccosphere. Large coccoliths tend to 282 have a large coverage area, which in contrast to the assumption that, in the population of a strain 283 of coccolithophore, there is a positive correlation between coccolith size and coccosphere surface 284 area. But this relationship may have been observed between different species and/or strains 285 (Gibbs et al. 2013; Henderiks 2008; Henderiks et al. 2012; Sheward 2016). Overall, for a cell 286 with a layer of completely interlocking coccoliths, the effective coverage area of coccoliths must 287 adjust to the surface area.

288

Coccolith topology of a specific coccolithophore. The coccolith geometry of the coccolithophore family Braarudosphaera is a mystery. This family is distinguished by having a coccosphere formed of 12 five-fold symmetric pentaliths (identical pentagonal faces), which are perfectly arranged into a regular dodecahedron (Young et al. 2003). A polyhedron with 12 pentagons is one of the possible coccolith arrangement patterns in E. huxleyi cells (Supplementary Table 1). The regular dodecahedron is one of the five Platonic solids, thus, pentaliths cannot interlock with others. Because of the geometric constraints, a regular dodecahedron is the only choice for coccospheres of Braarudosphaera. This indicates that Braarudosphaera spp. cells cannot change sizes, because the pentalith number must be 12 , and 
298

299

300

301

302

303

304

305

306

307

308

309

310

311

312

313

314

315

316

317

318

319

320

321

322

323

324

cells could not divide if the cell surface must be totally covered by pentaliths. Braarudosphaera spp. cells contain visible chloroplasts, but they have not been successfully grown in culture (Hagino et al. 2013; Young et al. 2003). The coccospheres of Braarudosphaeara do not contain perforations, which limited interactions between the cells and surrounding seawater, and Siesser (1993) speculated that Braarudosphaeara may be related to a calcareous dinoflagellate cyst. Further study based on phylogenetic analyses suggested that $B$. bigelowii belongs to the class Prymnesiophyceae, and it is most likely related to the orders Isochrysidales and Coccolithales, and two unidentified haptophytes (Takano et al. 2006). Therefore, we propose that the observed coccospheres of Braarudosphaera spp. actually belong to a resting or cyst stage of the life cycle.

Assembliy processes of coccosphere. Although this study suggested that the coccolith topology is actually a direct mathematical solution to maintain full coverage by coccoliths on the cell surface, knowledge of how coccoliths are arranged to form a coccosphere is limited. Taylor et al. (2007) recorded the formation and secretion processes of three coccoliths in a completely predecalcified $C$. pelagicus cell. They also released a video that clearly demonstrated that the first and second coccoliths were separated by a wide distance and that the third coccolith was secreted between the first and the second. The three coccoliths were moved to arrange them in a curvedlinear order on the cell surface. This suggests that the cell sensed the positions of coccoliths which directly attached on the cell membrane. Thus, the assembling process of coccosphere is under precise control, but the mechanisms remain unclear. E. huxleyi may use the same mechanisms as $C$. pelagicus to construct a coccosphere, because of similar coccolith morphology and interlocking patterns.

\section{Conclusions}

This study determined that, because of geometric limits, small coccoliths tend to interlock with fewer and larger coccoliths to sustain a full coverage on the spherical cell surface, and vice versa. E. huxleyi cells arrange individual coccoliths to interlock with four to six others, resulting 
325 in each coccosphere containing at least six coccoliths. This study used Euler's polyhedron

326 formula and $\mathrm{CaGe}$ simulation software, validated with the geometries of coccoliths, to

327 demonstrate that the proposed coccolith arrangement pattern as the only mathematical solution to

328 form coccospheres. In addition, the number of coccoliths per coccosphere must adapt to with

329 changing cell surface area due to photosynthesis, respiration, and cell division. E. huxleyi cells

330 divide at the proper size to ensure that each daughter cell can generate at least six coccoliths. Our

331 methods may useful to analyze the coccolith topology of other coccolithophore species. Future

332 work is needed to determine the actual cellular mechanisms for sensing and regulating

333 coccosphere geometry.

334

\section{Acknowledgements}

336

337

338

339

340

341

342

343

344

345

346

347

348

349

350

351

352

353

354

355

356

357

We would like to thank the anonymous reviewers for the valuable improvements that they have helped us make to this manuscript. We thank LetPub (www.letpub.com) for its linguistic assistance during the preparation of this manuscript.

\section{References:}

Amodeo AA, and Skotheim JM. 2016. Cell-size control. Cold Spring Harbor perspectives in biology 8:a019083.

Brinkmann G, Friedrichs OD, Lisken S, Peeters A, and Van Cleemput N. 2010. CaGe-a virtual environment for studying some special classes of plane graphs - an update. Match Communications In Mathematical And In Computer Chemistry 63:533-552.

Damodaran SP, Eberhard S, Boitard L, Rodriguez JG, Wang Y, Bremond N, Baudry J, Bibette J, and Wollman FA. 2015. A millifluidic study of cell-to-cell heterogeneity in growth-rate and cell-division capability in populations of isogenic cells of Chlamydomonas reinhardtii. PLoS One 10:e118987. 10.1371/journal.pone.0118987

Dixon HH. 1900. On the Etructure of coccospheres and the origin of coccoliths. Proceedings of the Royal Society of London 66:305-315.

Gibbs SJ, Poulton AJ, Bown PR, Daniels CJ, Hopkins J, Young JR, Jones HL, Thiemann GJ, O'Dea SA, and Newsam C. 2013. Species-specific growth response of coccolithophores to Palaeocene-Eocene environmental change. Nature Geoscience 6:218-222. 10.1038/ngeo1719

Gibson MC, Patel AB, Nagpal R, and Perrimon N. 2006. The emergence of geometric order in proliferating metazoan epithelia. Nature 442:1038-1041.

Grünbaum B, and Motzkin TS. 1963. The number of hexagons and the simplicity of geodesics on certain polyhedra. Canadian Journal of Mathematics 15:744-751. 
Hagino K, Onuma R, Kawachi M, and Horiguchi T. 2013. Discovery of an endosymbiotic nitrogen-fixing cyanobacterium UCYN-A in Braarudosphaera bigelowii (Prymnesiophyceae). PLoS One 8:e81749. 10.1371/journal.pone.0081749

Henderiks J. 2008. Coccolithophore size rules - Reconstructing ancient cell geometry and cellular calcite quota from fossil coccoliths. Marine Micropaleontology 67:143-154. 10.1016/j.marmicro.2008.01.005

Henderiks J, Winter A, Elbrächter M, Feistel R, van der Plas A, Nausch G, and Barlow R. 2012. Environmental controls on Emiliania huxleyi morphotypes in the Benguela coastal upwelling system (SE Atlantic). Marine Ecology Progress Series 448:51-66.

Hoffmann R, Kirchlechner C, Langer G, Wochnik AS, Griesshaber E, Schmahl WW, and Scheu C. 2015. Insight into Emiliania huxleyi coccospheres by focused ion beam sectioning. Biogeosciences 12:825-834. 10.5194/bg-12-825-2015

Jaya BN, Hoffmann R, Kirchlechner C, Dehm G, Scheu C, and Langer G. 2016. Coccospheres confer mechanical protection: New evidence for an old hypothesis. Acta Biomater 42:258-264. 10.1016/j.actbio.2016.07.036

Kiyomitsu T. 2015. Mechanisms of daughter cell-size control during cell division. Trends in Cell Biology 25:286295.

Klaveness D. 1972. Coccolithus huxleyi (Lohm.) Kamptn II. The flagellate cell, aberrant cell types, vegetative propagation and life cycles. British Phycological Journal 7:309-318.

Langer G, and Bode M. 2011. $\mathrm{CO}_{2}$ mediation of adverse effects of seawater acidification in Calcidiscus leptoporus. Geochemistry, Geophysics, Geosystems 12:n/a-n/a. 10.1029/2010gc003393

Langer G, Probert I, Nehrke G, and Ziveri P. 2011. The morphological response of Emiliania huxleyi to seawater carbonate chemistry changes: an inter-strain comparison. Journal of Nannoplankton Research 32:29-34.

Lewis FT. 1926. The effect of cell division on the shape and size of hexagonal cells. The Anatomical Record 33:331-355.

Lewis FT. 1928. The correlation between cell division and the shapes and sizes of prismatic cells in the epidermis of cucumis. The anatomical record 38:341-376.

Lewis FT. 1943. A geometric accounting for diverse shapes of 14-hedral cells: the transition from dodecahedra to tetrakaidecahedra. American Journal of Botany:74-81.

Paasche E. 2002. A review of the coccolithophorid Emiliania huxleyi (Prymnesiophyceae), with particular reference to growth, coccolith formation, and calcification-photosynthesis interactions. Phycologia 40:503-529.

Price NM, Harrison GI, Hering JG, Hudson RJ, Nirel PMV, Palenik B, and Morel FMM. 1989. Preparation and chemistry of the artificial algal culture medium Aquil. Biology Oceanography 6:443-461.

Sheward RM. 2016. Cell size, coccosphere geometry and growth in modern and fossil coccolithophores. University of Southampton.

Sheward RM, Poulton AJ, Gibbs SJ, Daniels CJ, and Bown PR. 2017. Physiology regulates the relationship between coccosphere geometry and growth phase in coccolithophores. Biogeosciences 14:1493-1509. 10.5194/bg14-1493-2017

Siesser WG. 1993. Calcareous nanoplankton. In: Lipps JH, ed. Fossil prokaryotes and protists. Boston: Blackwell Scientific Publications, 169-201.

Su H. 1987. The characteristics of maximum inscribed and minimum circumscribed polygons of ellipse. Teaching Mathematics 6:22-26.

Sviben S, Gal A, Hood MA, Bertinetti L, Politi Y, Bennet M, Krishnamoorthy P, Schertel A, Wirth R, Sorrentino A, 
399

400

401

402

403

404

405

406

407

408

409

410

411

412

413

414

415

416

417

418

419

420

421

422
Pereiro E, Faivre D, and Scheffel A. 2016. A vacuole-like compartment concentrates a disordered calcium phase in a key coccolithophorid alga. Nat Commun 7:11228. 10.1038/ncomms11228

Takano Y, Hagino K, and Tanaka Y. 2006. Phylogenetic affinities of an enigmatic nannoplankton, Braarudosphaera bigelowii based on the SSU rDNA sequences. Marine Micropaleontology 60:145-156.

Taylor AR, Russell MA, Harper GM, Collins TfT, and Brownlee C. 2007. Dynamics of formation and secretion of heterococcoliths by Coccolithus pelagicus ssp. braarudii. European Journal of Phycology 42:125-136. $10.1080 / 09670260601159346$

Weaire D, and Rivier N. 1984. Soap, cells and statistics-random patterns in two dimensions. Contemporary Physics 25:59-99. 10.1080/00107518408210979

Wilbur KM, and Watabe N. 1963. Experimental studies on calcification in molluscs and the alga Cocolithus huxleyi. Annals of the New York Academy of Sciences 109:82-112.

$\mathrm{Xu}$ K, and Gao K. 2015. Solar UV irradiances modulate effects of ocean acidification on the coccolithophorid Emiliania huxleyi. Photochemistry and photobiology 91:92-101. 10.1111/php.12363

Xu K, Xu Y, Ji D, Chen T, Chen C, and Xie C. 2017. Cells tile a flat plane by controlling geometries during morphogenesis of Pyropia thalli. PeerJ 5:e3314. 10.7717/peerj.3314

Young J, Bown P, and Lees J. 2017. 'Cylindralithus' Nannotax3 website.

Young JR, Didymus JM, Brown PR, Prins B, and Mann S. 1992. Crystal assembly and phylogenetic evolution in heterococcoliths. Nature 356:516-518.

Young JR, Geisen M, Cros L, Kleijne A, Probert I, Sprengel C, and Ostergaard J. 2003. A guide to extant coccolithophore taxonomy. JNannoplankton Res 1:1-125.

Zondervan I, Rost B, and Riebesell U. 2002. Effect of $\mathrm{CO}_{2}$ concentration on the PIC/POC ratio in the coccolithophore Emiliania huxleyi grown under light-limiting conditions and different daylengths. Journal of Experimental Marine Biology and Ecology 272:55-70. 
Figure 1

Geometry of coccoliths and proto-coccoliths.

(a) A frontal view of a coccolith. (b) A diagram of a side view of a coccolith. Angle $\alpha$ refers to the angle between the distal shield and central area. DSL, DSW and OSW in front view (A) and side view (B) of coccolith. Length and width of proto-coccolith (C).

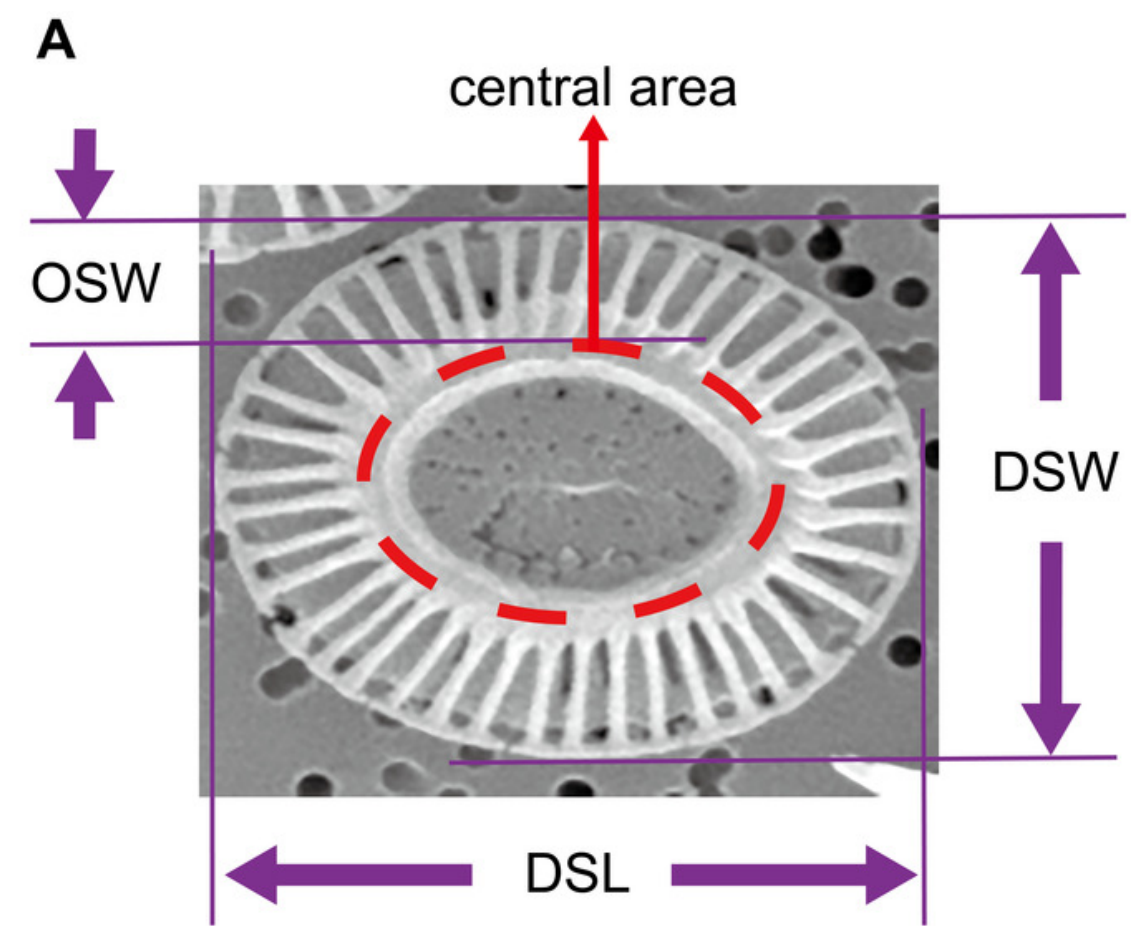

B

C

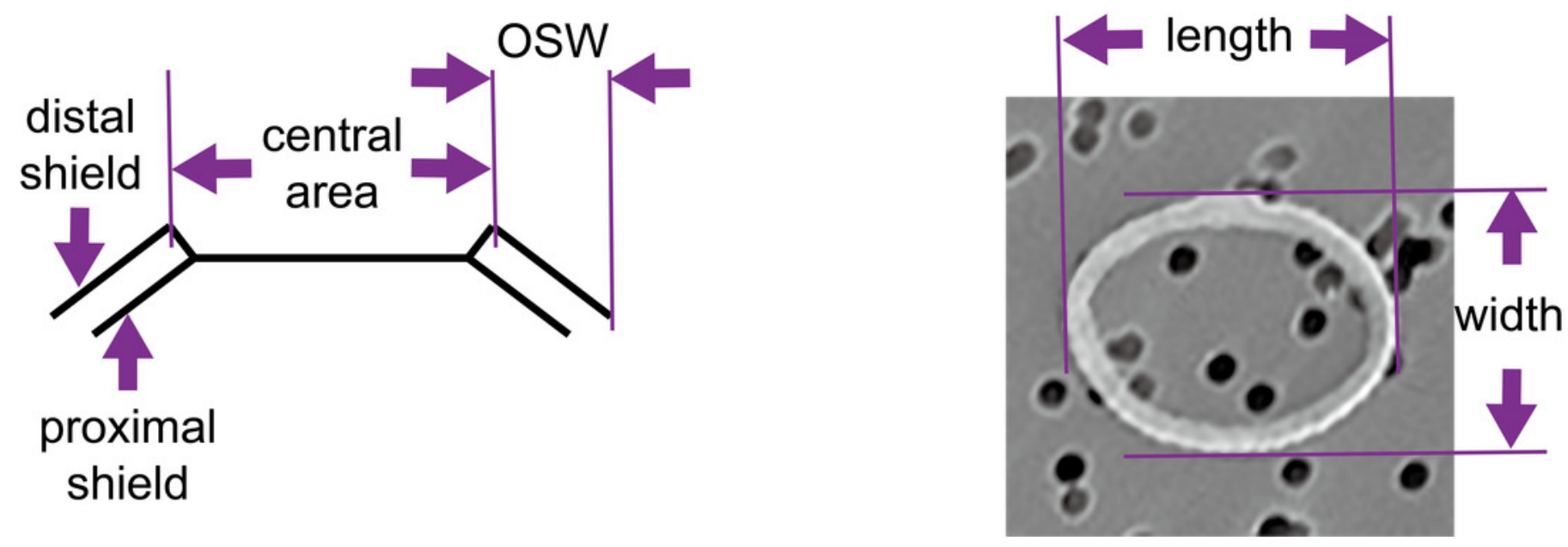


Figure 2

Photos of coccospheres of $E$. huxleyi.

Coccospheres with different numbers of coccolith ( $6-22$ coccoliths). White bars are $1 \mu \mathrm{m}$. Red numbers on the coccoliths indicate bordering coccoliths. 


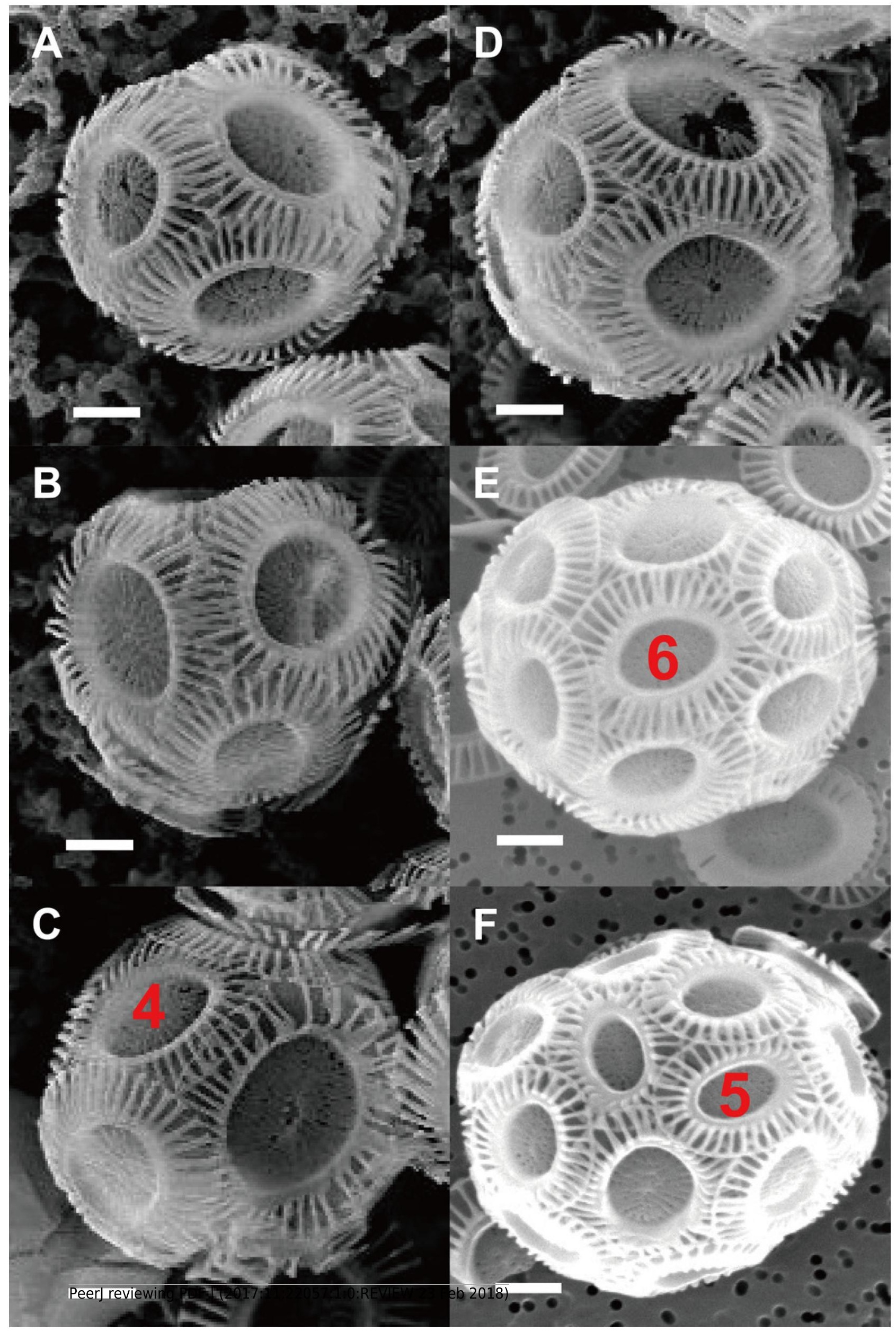


Figure 3 (on next page)

Inscribed tri- to heptagons in coccoliths.

Large and small blue ellipses of oval-shaped rings represent edges of distal shield and central area of coccoliths, respectively. Maximum, average, and minimum values of DSW/DSL and OSW/DSL are the derived from Table 1 . Green ellipse represents the maximum inscribed ellipse of the maximum inscribed polygon (in red color) of coccolith. The ratio of length of green ellipse to DSL appear above the photos. 

$\mathrm{L}_{\text {green }} / \mathrm{DSL}=0.75 \quad \mathrm{~L}_{\text {green }} / \mathrm{DSL}=0.8 \quad \mathrm{~L}_{\text {green }} / \mathrm{DSL}=0.85$

OSW/DSL $=0.25$
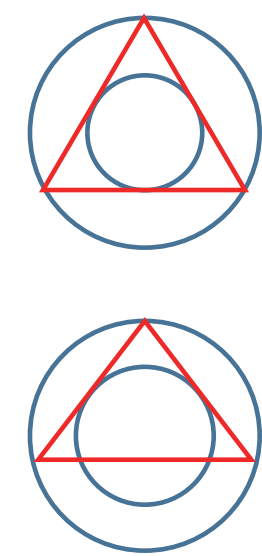
$=1 \quad=0.19$
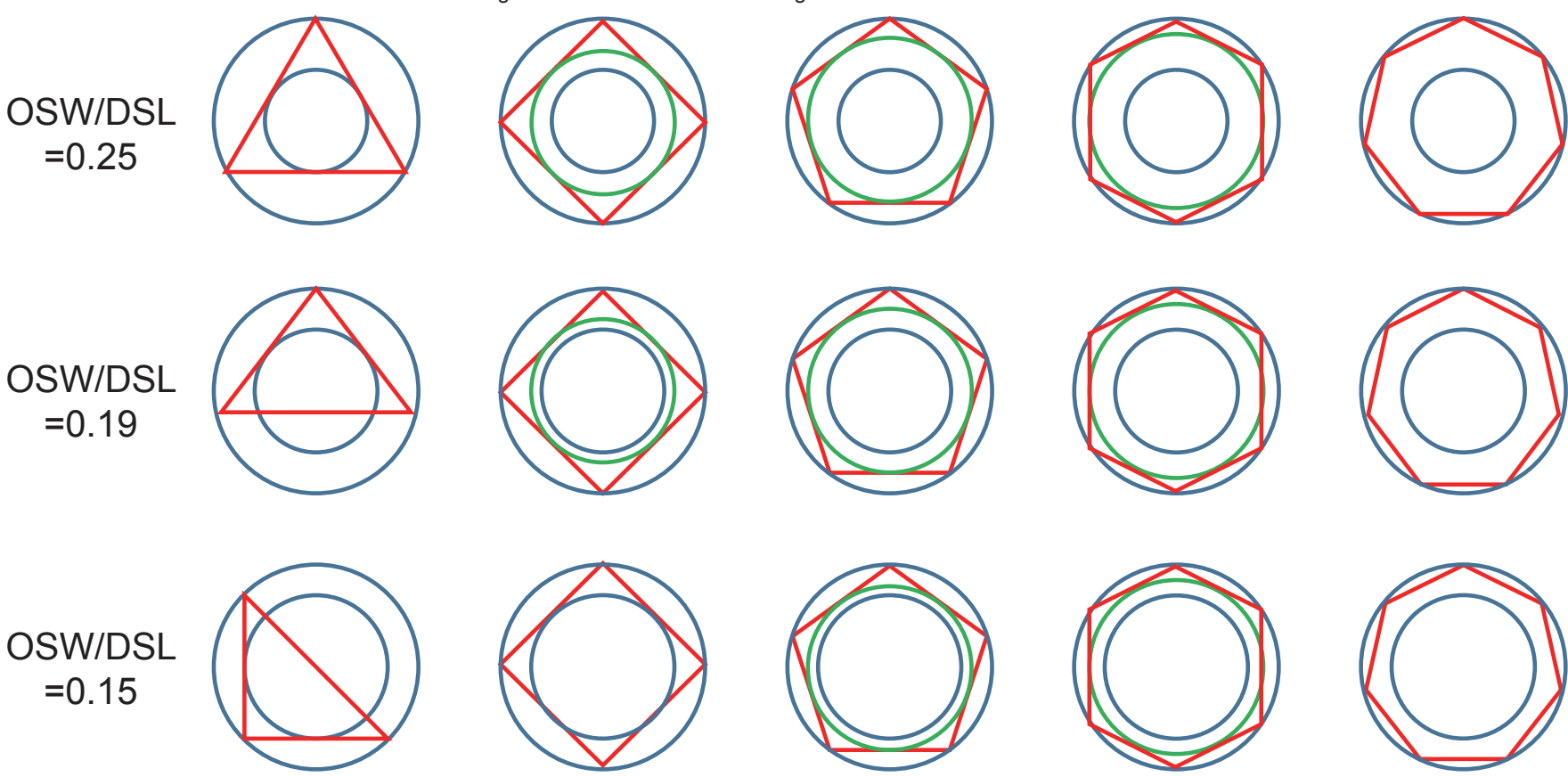

DSW/DSL OSW/DSL
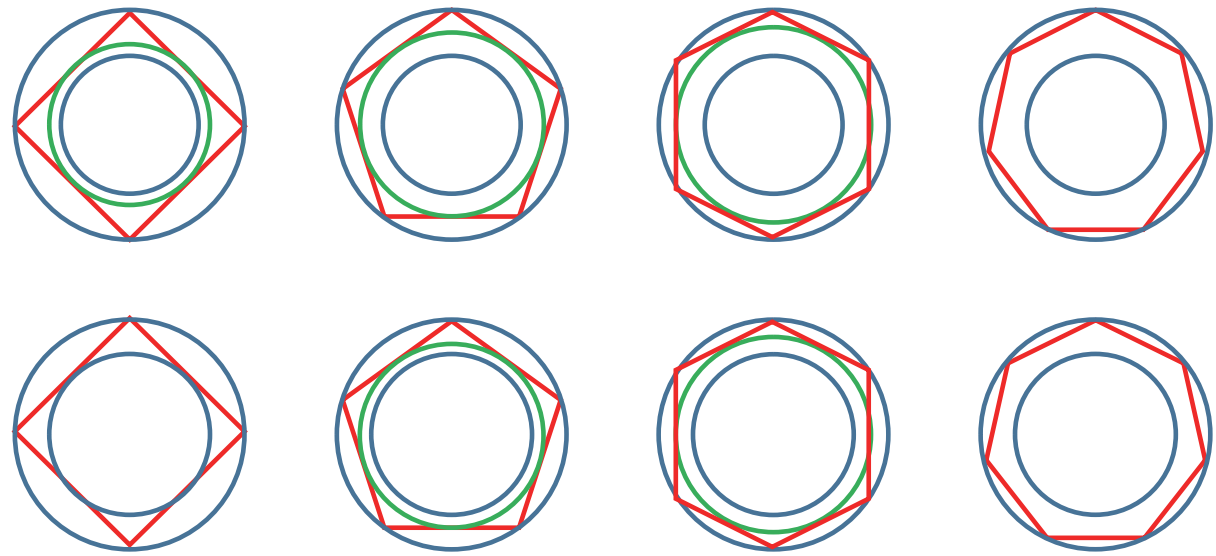

OSW/DSL $=0.25$
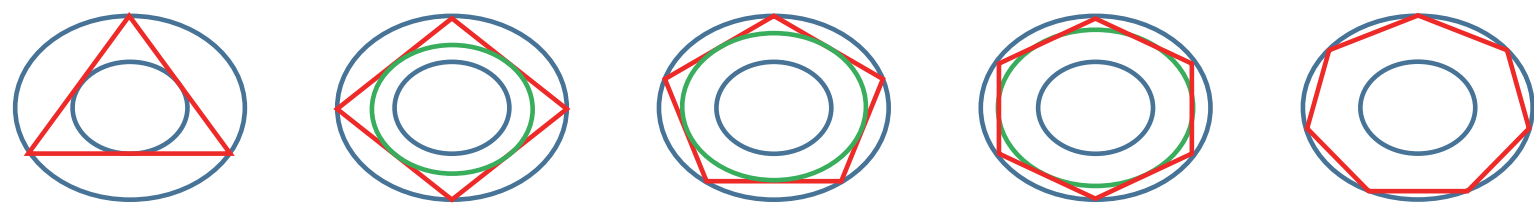

DSW/DSL OSW/DSL $=0.81$ $=0.19$
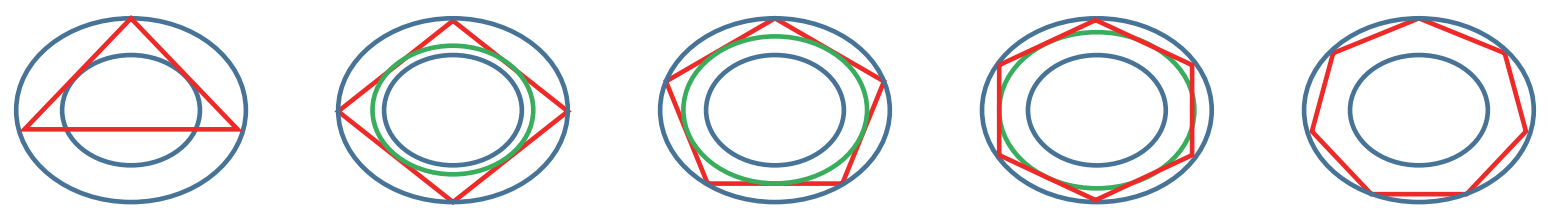

OSW/DSL $=0.15$
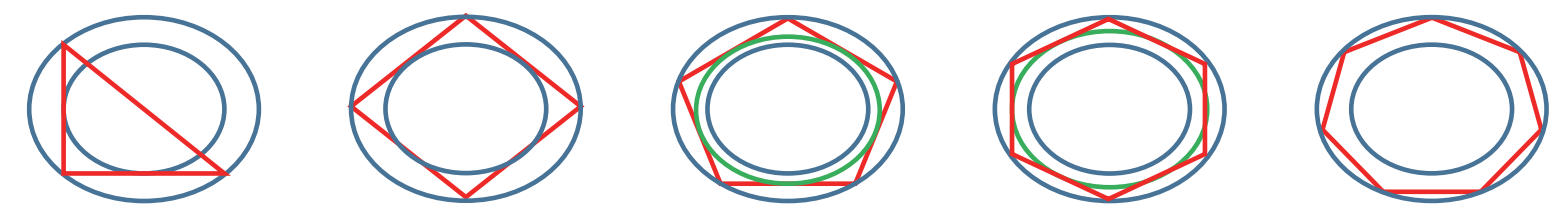

OSW/DSL
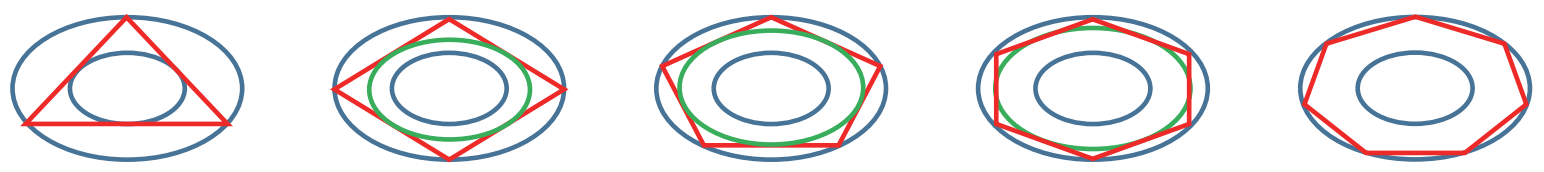

DSW/DSL OSW/DSL
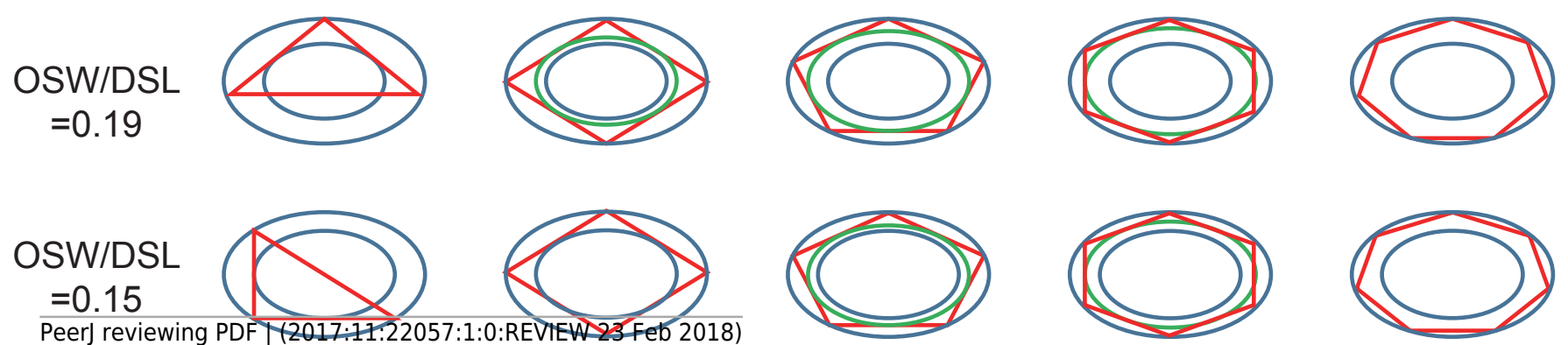
Figure 4 (on next page)

Simulation of interlocked coccoliths on a 2D plane.

Central coccolith interlocked with three, four, five, six, and seven others (A-E). DSW/DSL of all coccoliths were set to an average value of 0.81 . Values of $\mathrm{OSW}_{\mathrm{CC}} / \mathrm{DSL} \mathrm{C}_{\mathrm{CC}}, \mathrm{OSW}_{\mathrm{BCS}} / \mathrm{DSL}_{\mathrm{BCS}}$, and $\mathrm{DSL}_{\mathrm{BCS}} / \mathrm{DSL}_{\mathrm{cc}}$ appear above the photos. 
$\quad \mathrm{OSW}_{\mathrm{CC}} / \mathrm{DSL}_{\mathrm{cC}}=0.37$

A $\quad \operatorname{OSW}_{\mathrm{BCs}} / \mathrm{DSL}_{\mathrm{BCs}}=0.19$ $\mathrm{DSL}_{\mathrm{BCS}} / \mathrm{DSL}_{\mathrm{CC}}=1.4$

P다년 $=0.8$
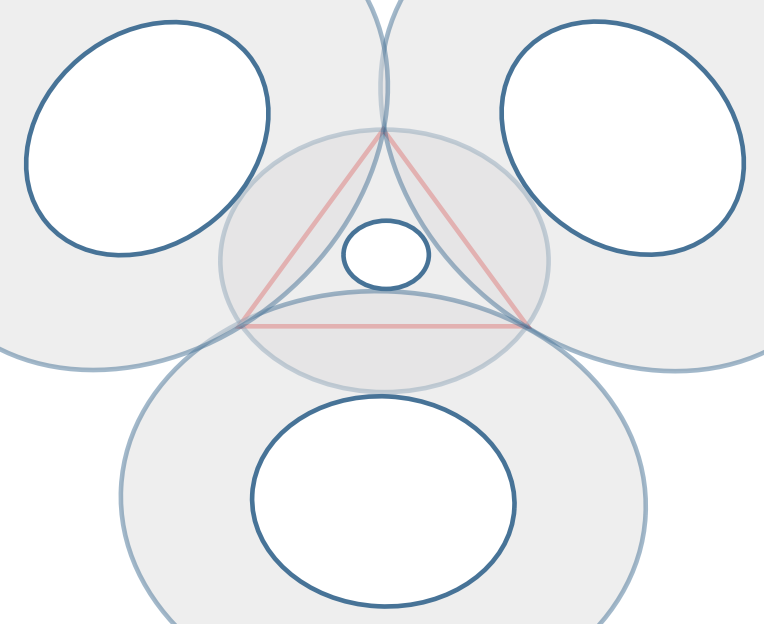

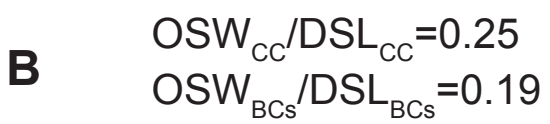

$\mathrm{DSL}_{\mathrm{BCs}} / \mathrm{DSL} \mathrm{CC}_{\mathrm{CC}}=1.3$

\section{$\mathrm{DSW} / \mathrm{DSL}=0.8$}

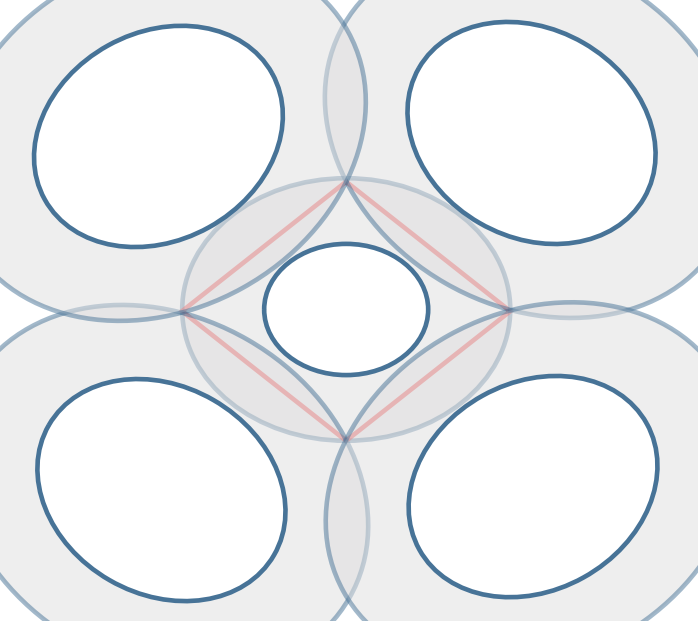

Peer) reviewing PDF | (2017:11:22057:1:0:REVIEW 23 Feb 2018)
$\mathrm{OSW}_{\mathrm{cc}} / \mathrm{DSL}_{\mathrm{cc}}=0.19$

C $\quad \operatorname{OSW}_{\mathrm{BCs}} / \mathrm{DSL}_{\mathrm{BCs}}=0.19$ $\mathrm{DSL}_{\mathrm{BCs}} / \mathrm{DSL}_{\mathrm{CC}}=1$

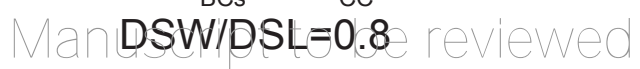

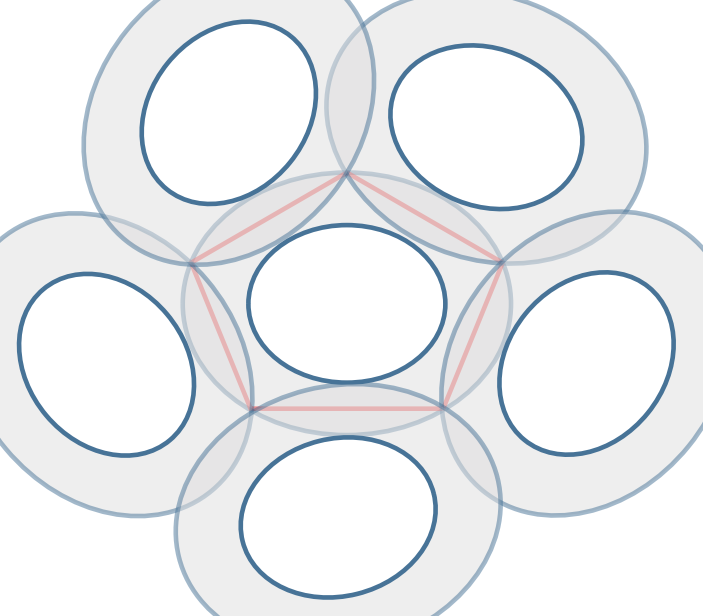

D $\quad \begin{aligned} & \mathrm{OSW}_{\mathrm{CC}} / \mathrm{DSL}_{\mathrm{CC}}=0.19 \\ & \mathrm{OSW}_{\mathrm{BCs}} / \mathrm{ISL}_{\mathrm{BCs}}=0.19 \\ & \mathrm{DSL}_{\mathrm{BCs}} / \mathrm{ISSL}_{\mathrm{CC}}=0.8 \\ & \mathrm{DSW} / \mathrm{DSL}=0.8\end{aligned}$
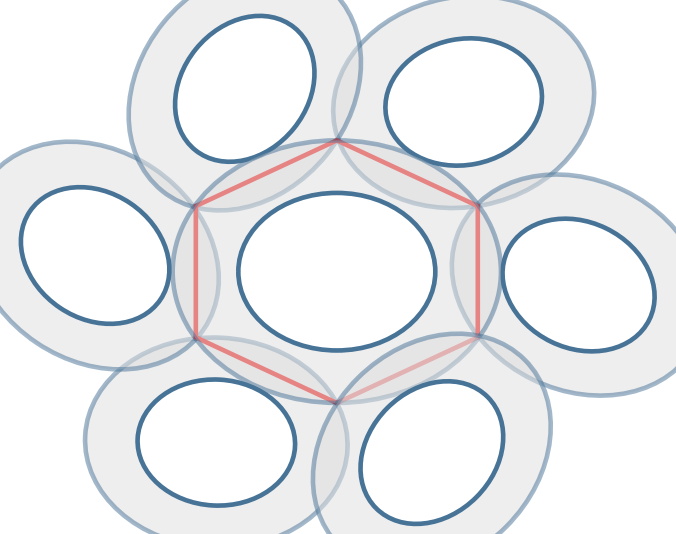

E $\quad \begin{aligned} & \mathrm{OSW}_{\mathrm{CC}} / \mathrm{DSL}_{\mathrm{CC}}=0.19 \\ & \operatorname{OSW}_{\mathrm{BCs}} / \mathrm{DSL}_{\mathrm{BCs}}=0.19\end{aligned}$ $\mathrm{DSL}_{\mathrm{BCs}} / \mathrm{DSL} \mathrm{CC}_{\mathrm{CC}}=0.75$ $\mathrm{DSW} / \mathrm{DSL}=0.8$

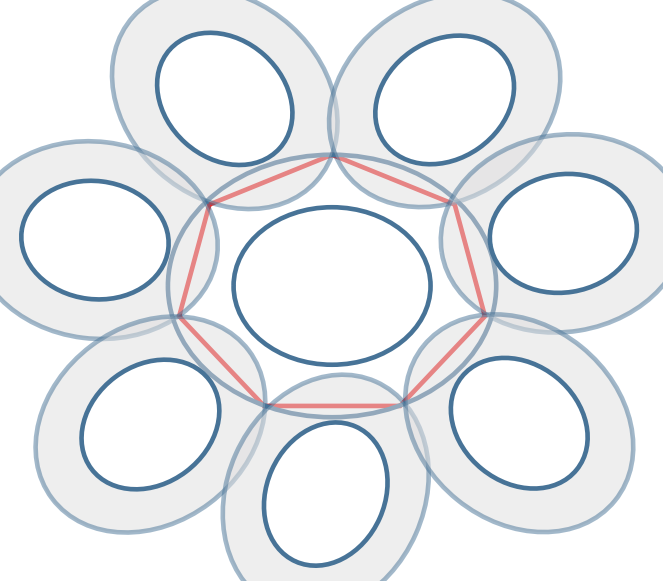


Figure $\mathbf{5}$ (on next page)

Each coccolith interlocked with seven others.

DSW/DSL and OSW/DSL were set at average values of 0.81 and 0.19 , respectively. Values of $\mathrm{DSL}_{\mathrm{BCs}} / \mathrm{DSL} \mathrm{L}_{\mathrm{cc}}$ appear above photos. Red arrows indicate that overlaps transect the central area of the central coccolith $(A)$, or the bordering coccoliths because of they should not on the same plane of the central coccolith (B). Blue arrows indicate loose interlock of bordering coccoliths (D-F). 
A $\mathrm{DSL}_{\mathrm{BCs}} / \mathrm{DSL}_{\mathrm{CC}}=0.6$

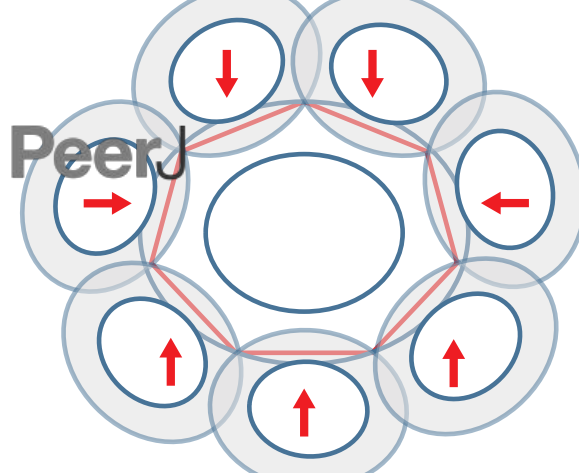

B $\mathrm{DSL}_{\mathrm{BCs}} / \mathrm{DSL}_{\mathrm{Cc}}=0.7$

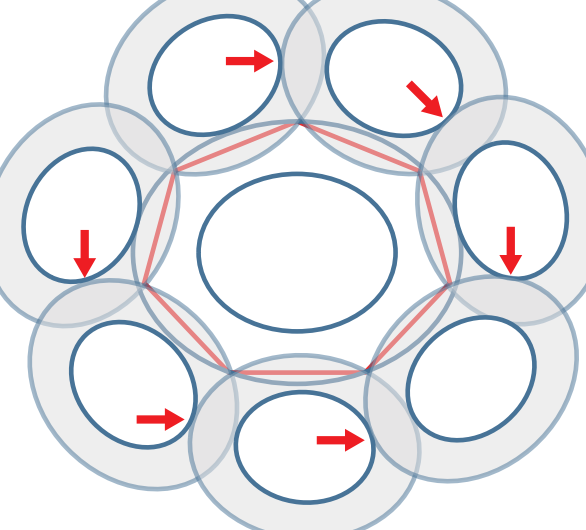

c $\mathrm{DSL}_{\mathrm{BCs}} / \mathrm{DSL}_{\mathrm{CC}}=0.75$

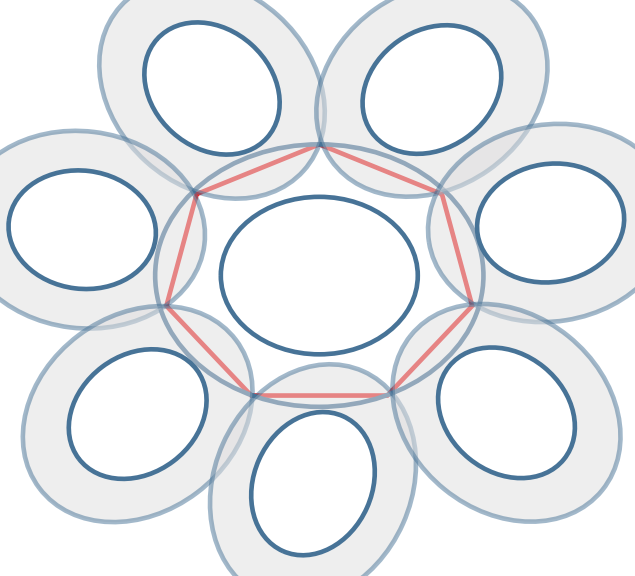

c $\mathrm{DSL}_{\mathrm{BCs} / \mathrm{DSL}_{\mathrm{CC}}=0.8}$

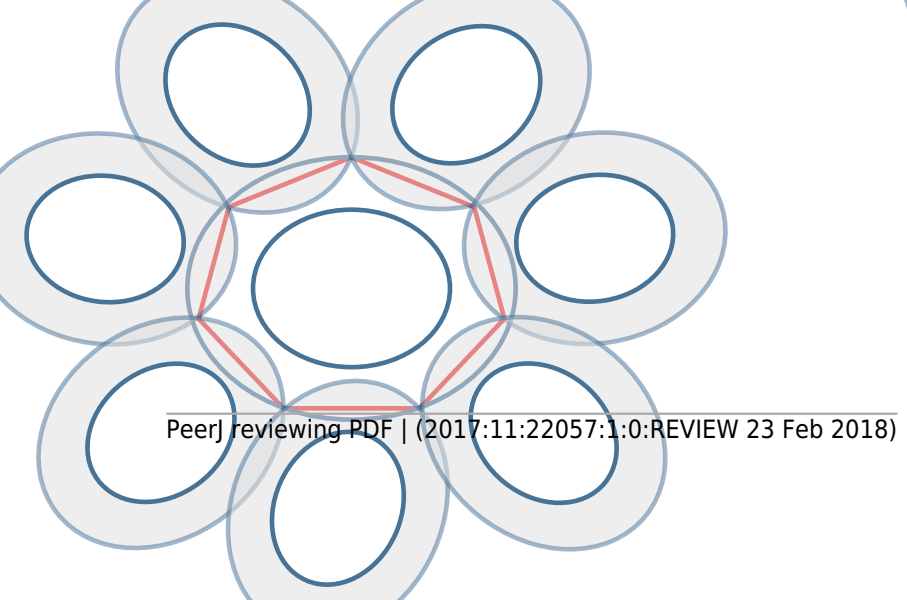

D $\mathrm{DSL}_{\mathrm{BCs}} / \mathrm{DSL}_{\mathrm{cc}}=0.85$

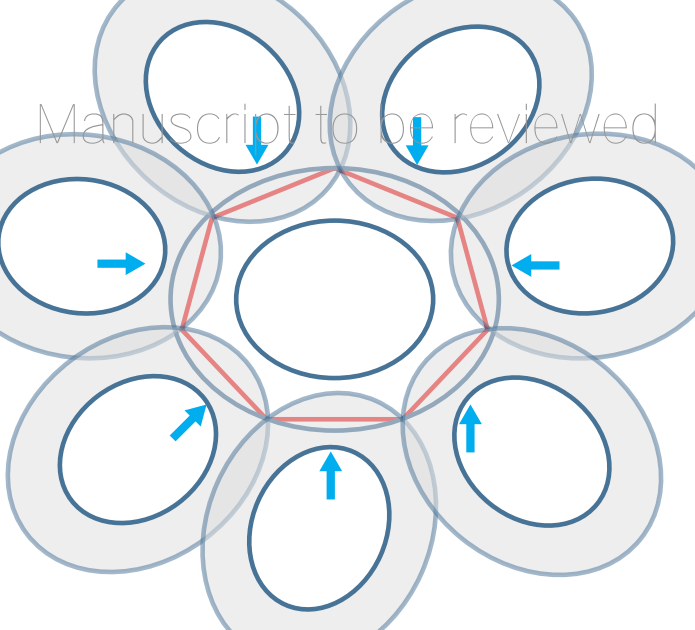

E $\quad \mathrm{DSL}_{\mathrm{BCs}} / \mathrm{DSL} \mathrm{L}_{\mathrm{CC}}=0.9$

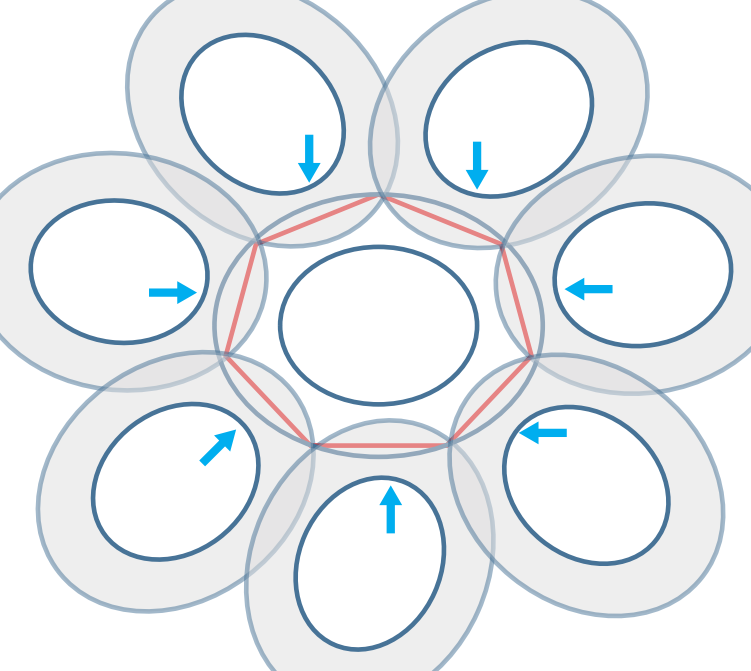

F $\quad \mathrm{DSL}_{\mathrm{BCs}} / \mathrm{DSL}_{\mathrm{CC}}=1$

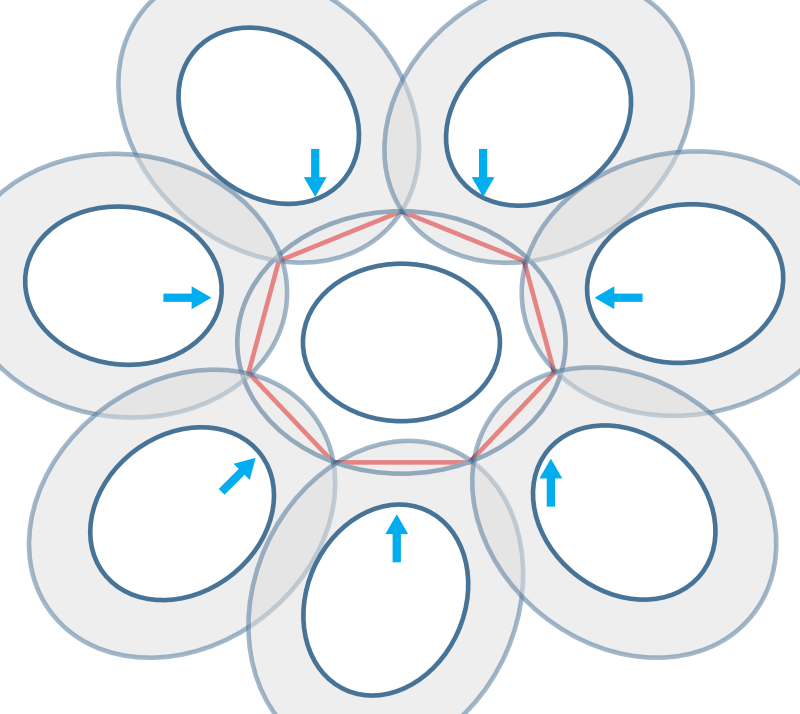




\section{Figure 6}

Coccosphere of E. huxleyi with an incomplete coccolith.

White bar is $1 \mu \mathrm{m}$ and white arrow demonstrates incomplete coccolith.

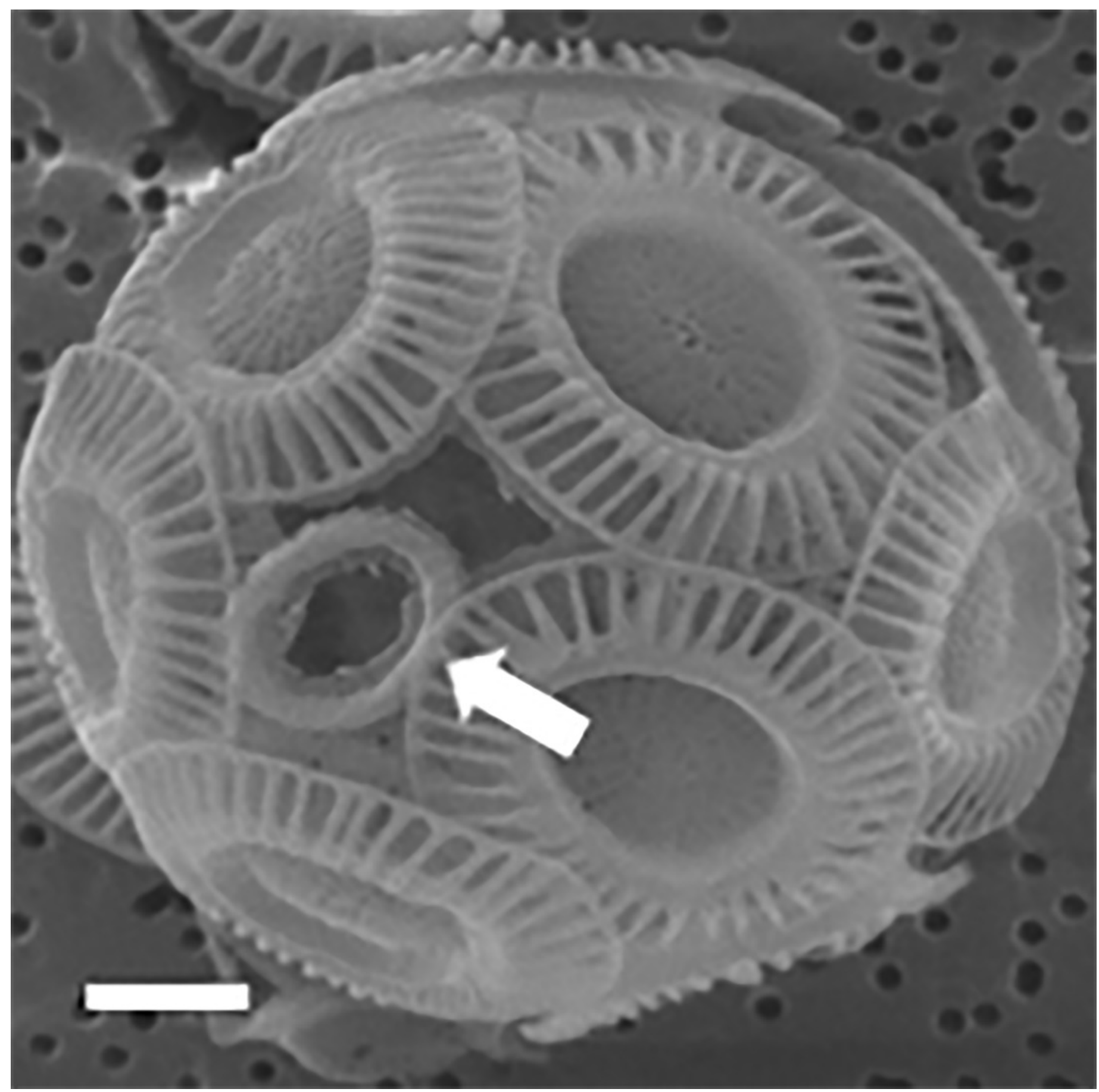




\section{Figure 7}

Simulated structures of typical coccospheres.

3D (A) and 2D (B) structures of polyhedra simulated by CaGe. The number of faces appears above the structures. Polygon compositions and isomer numbers are shown in Supplementary Table 1. 
A
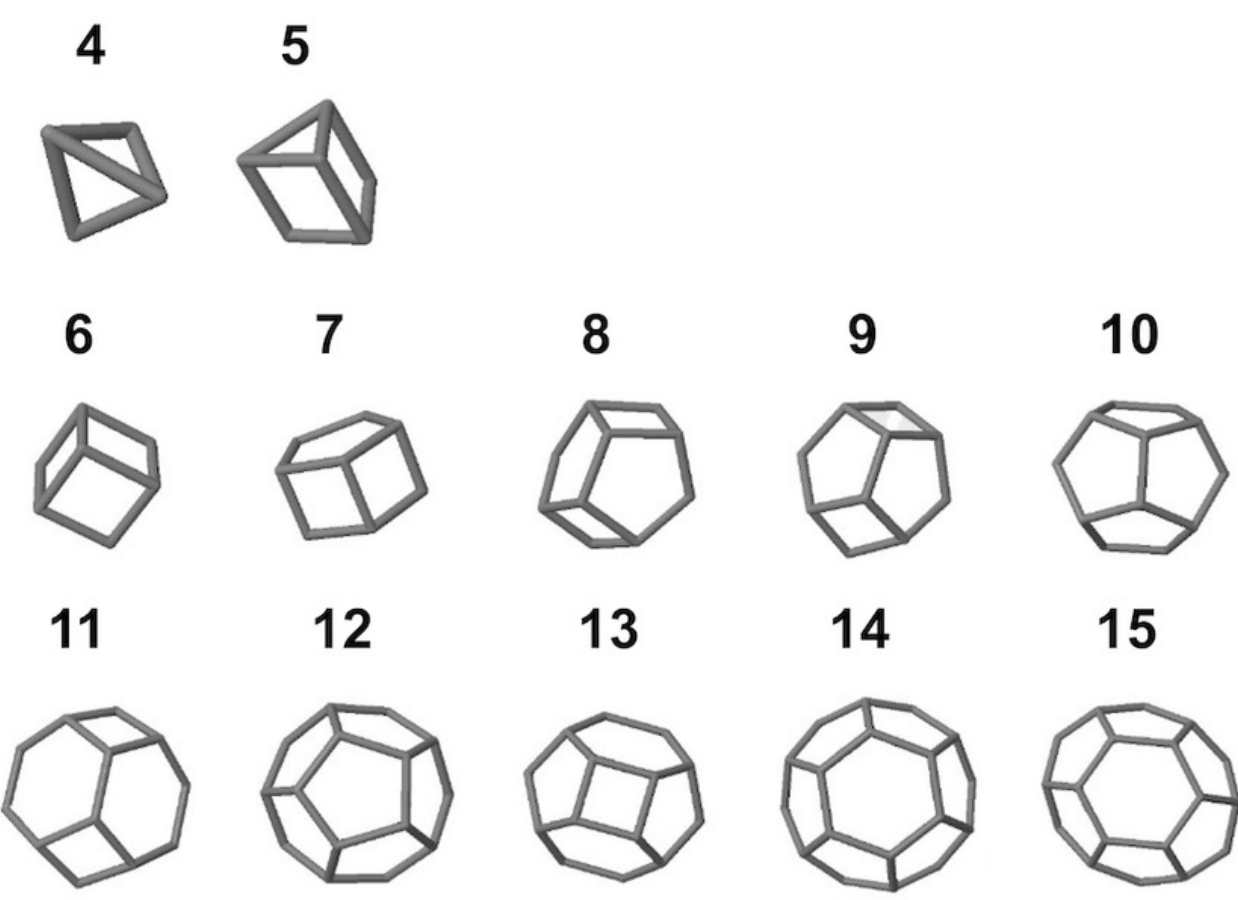

15

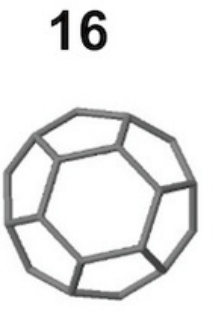

17

18

19
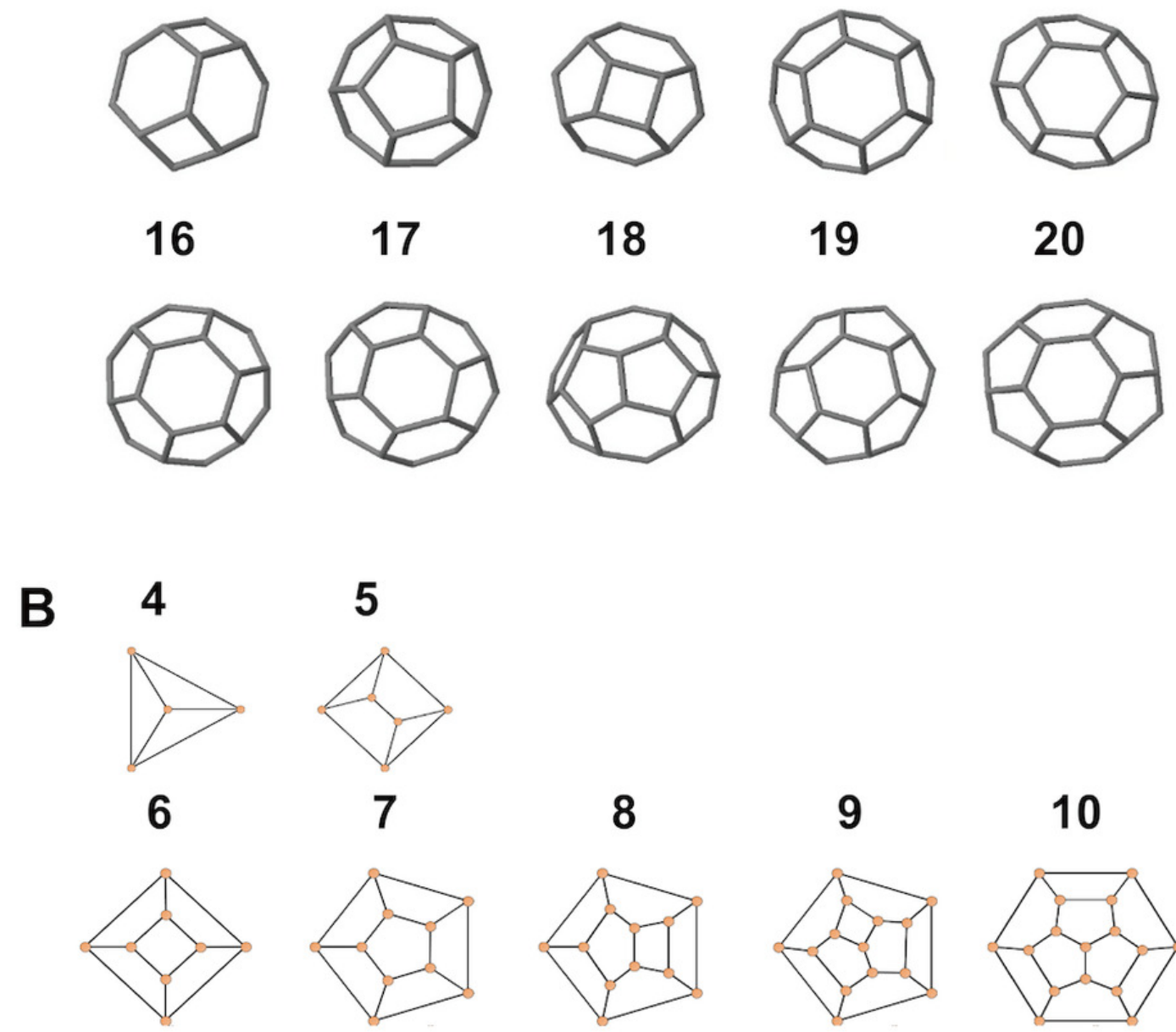

7

8

9

10

11
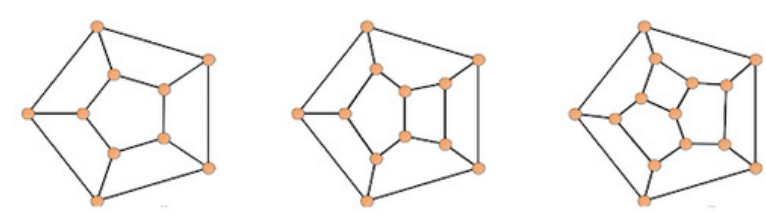

14
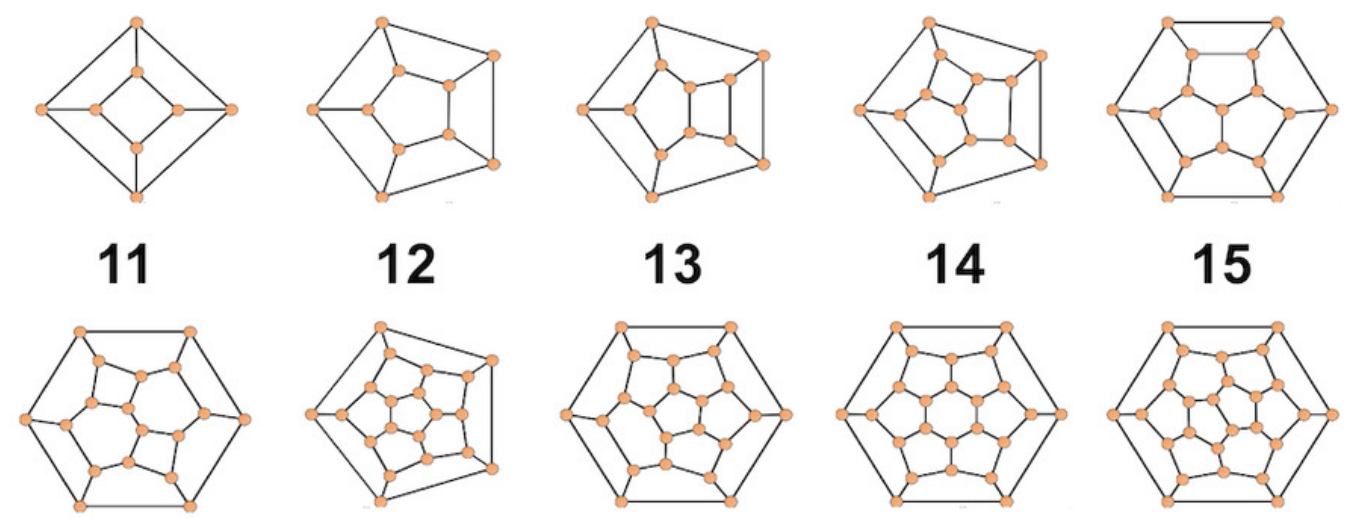

13
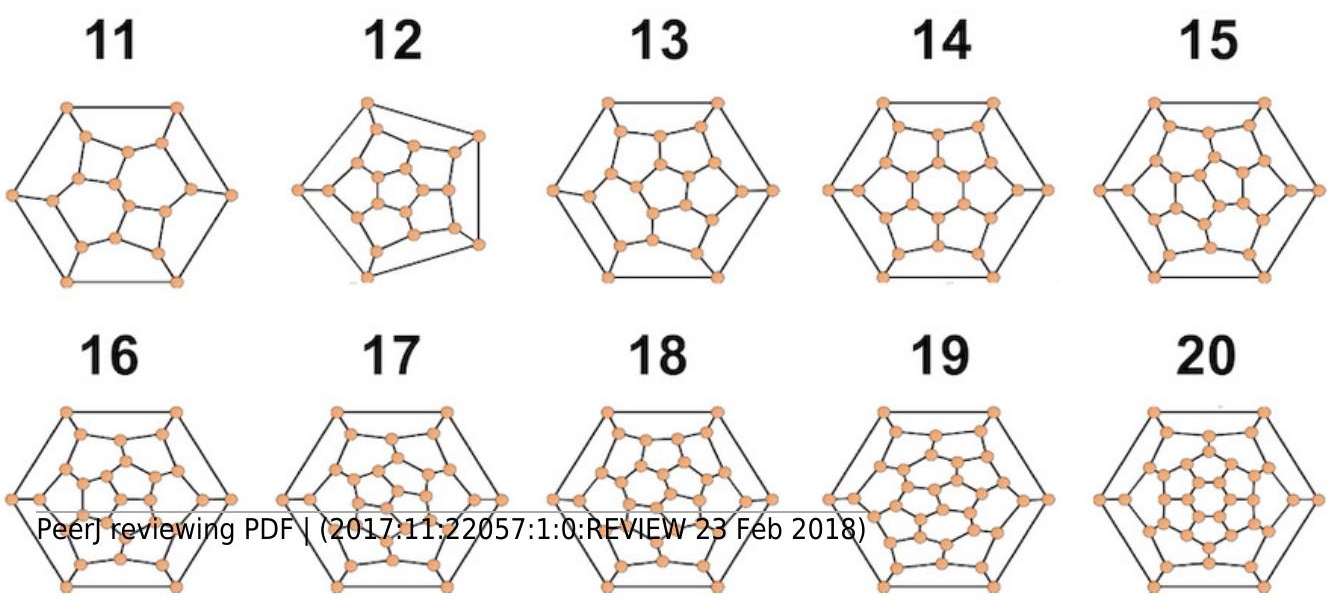

18

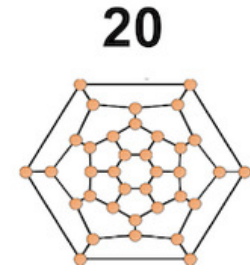


Figure 8

Positive linear relationship between coccoliths per cell and coccosphere surface area.

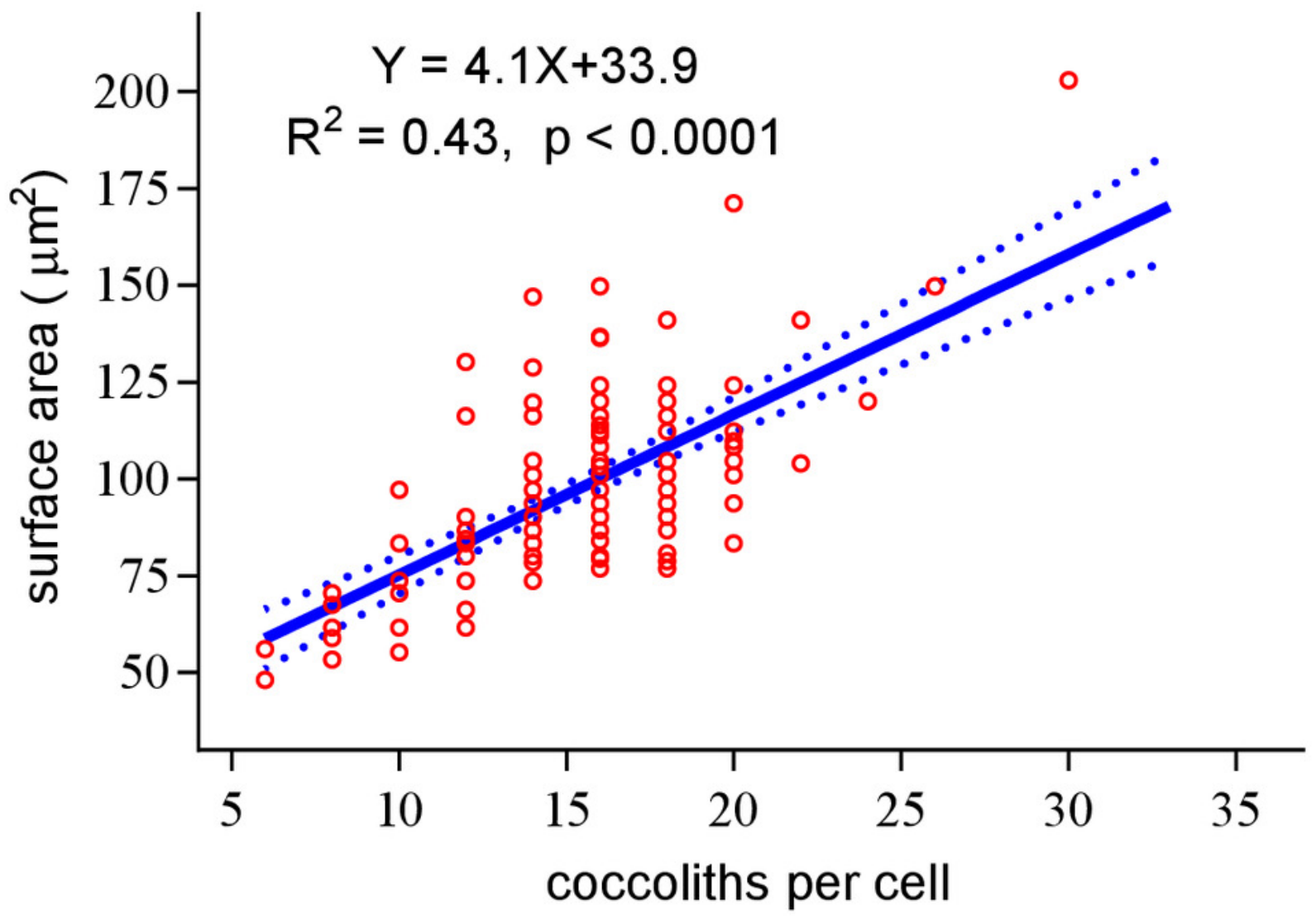




\section{Table $\mathbf{1}$ (on next page)}

Geometric data for coccolith and proto-coccolith, coccosphere diameter, and coccoliths per cell. 


\begin{tabular}{|c|c|c|c|c|}
\hline Sample & & Mean \pm SD & Range & $n$ \\
\hline \multirow{5}{*}{ Normal coccoliths } & distal shield length (DSL, $\mu \mathrm{m})$ & $3.04 \pm 0.40$ & $2.05-4.38$ & 1,918 \\
\hline & distal shield width (DSW, $\mu \mathrm{m})$ & $2.45 \pm 0.37$ & $1.34-3.92$ & 1,918 \\
\hline & DSW/DSL & $0.81 \pm 0.07$ & $0.62-0.99$ & 1,918 \\
\hline & outer distal shield width (OSW, $\mu \mathrm{m})$ & $0.57 \pm 0.09$ & $0.36-0.84$ & 70 \\
\hline & OSW/DSL & $0.19 \pm 0.02$ & $0.15-0.25$ & 70 \\
\hline \multirow{3}{*}{ Proto-coccoliths } & length $(\mu \mathrm{m})$ & $1.86 \pm 0.21$ & $1.45-2.38$ & 72 \\
\hline & width $(\mu \mathrm{m})$ & $1.37 \pm 0.20$ & $0.98-1.90$ & 72 \\
\hline & length/width & $0.74 \pm 0.09$ & $0.56-0.94$ & 72 \\
\hline \multirow{2}{*}{ Coccospheres } & coccosphere diameter $(\mu \mathrm{m})$ & $5.54 \pm 0.63$ & $3.92-8.04$ & 156 \\
\hline & coccolith number per cell & $15.4 \pm 3.6$ & $6-30$ & 156 \\
\hline
\end{tabular}

2

3

4 